\title{
Pontocerebellar hypoplasia type 8
}

INSERM

\section{Source}

INSERM. (1999). Orphanet: an online rare disease and orphan drug data base.

Pontocerebellar hypoplasia type 8. ORPHA:324569

Pontocerebellar hypoplasia type $8(\mathrm{PCH} 8)$ is a novel very rare form of pontocerebellar hypoplasia (see this term) characterized clinically by progressive microencephaly, feeding difficulties, severe developmental delay, although walking may be achieved, hypotonia often associated with increased muscle tone of lower extremities and deep tendon reflexes, joint deformities in the lower extremities, and occasionally complex seizures. PCH 8 is caused by a loss-of-function mutation in the CHMP1A gene. MRI demonstrates a pontocerebellar hypoplasia with vermis and hemispheres equally affected and mild to severely reduced cerebral white matter volume with a fully formed very thin corpus callosum. 